\title{
The Influence of Perceived Teacher-Student Congruence on Students' Satisfaction in Physical Education
}

\author{
Sven Lindberg (Corresponding author) \\ German Institute for International Educational Research (DIPF), Frankfurt, Germany \\ Schloßstr. 29, 60486 Frankfurt am Main, Germany \\ Tel: 49-069-25707-224Ｅ-mail: lindberg@dipf.de \\ Marcus Hasselhorn \\ German Institute for International Educational Research (DIPF), Frankfurt, Germany \\ Schloßstr. 29, 60486 Frankfurt am Main, Germany \\ Tel: 49-069-25707-214 E-mail: hasselhorn@dipf.de

\section{Martin Lehmann} \\ German Institute for International Educational Research (DIPF), Frankfurt, Germany \\ Schloßstr. 29, 60486 Frankfurt am Main, Germany \\ Tel: 49-069-25707-211 E-mail: lehmann@dipf.de
}

Received: April 20, 2013 Accepted: May 6, 2013 Published: May 6, 2013

doi:10.5296/jse.v3i2.3555 URL: http://dx.doi.org/10.5296/jse.v3i2.3555

\begin{abstract}
The purpose of this study was to adapt the Leadership Scale for Sports (LSS; Chelladurai \& Saleh, 1980) to physical education (PE) classes, for measuring teacher behavior by taking consideration of the perspectives of students and teachers. We moreover examined the influence of teacher behavior and the perceived teacher-student congruence on the satisfaction of students. Two cross-sectional studies, an online survey with PE teachers and a school study where students responded to a questionnaire assessing students' perception and the preferred teacher behavior and teachers fill in a self-description form regarding their own
\end{abstract}




\section{Macrothink}

behavior. Participants for study 1 were 527 PE teachers (254 females and 273 males), aged 21-64 years $(M=42.11 ; S D=11.21)$. Participants in study 2 were 1452 students $(625$ females, 798 males and 29 unstated), aged $9-17$ years $(M=13.31 ; S D=1.49)$ and 18 PE teachers $(8$ females and 10 males), age 28-60 years $(M=49.87 ; S D=14.99)$. Confirmatory factor analysis and the reliability coefficients supported the view that the LSS is adequate for usage in PE. Hierarchical regression analyses demonstrated that teacher behavior influences the satisfaction of students. Moreover, perceived teacher-student congruence had a positive effect on students' satisfaction. The findings support the assumption that the LSS is a suitable instrument for an application in PE. Teachers should be concerned with their students' perception of their preferred teaching behavior in order to adapt to their needs and to foster their satisfaction with, and interest in, PE.

Keywords: Physical education, Students, Satisfaction, Teaching behavior 


\section{Introduction}

This study is concerned with adequately assessing teaching behavior in physical education from the perspectives of both the teachers themselves and their students. In accordance with relevant approaches to leadership behavior in sport science, which focus on a congruent fit-constellation of coaches and athletes (e.g. Chelladurai, 1978), we attempt to gain insights into factors that influence the satisfaction of students with physical education (PE).

More than other school subjects, physical education is concerned with demands and objectives that are directed toward the students' welfare, health and lifestyle (McCullick et al., 2012; Hagger, Chatzisarantis, Culverhouse, \& Biddle, 2003; Biddle, 2001). Moreover, PE is believed to influence the physical activity of students outside of school and to provide a basis for their future health-related engagement (Aarø, Wold, Kannas. \& Rimpala, 1986; Perry et al., 1990). Besides the influence of peers and family, PE teaching constitutes the major contributing factor for learning, acquiring and developing physical activity habits (Gee, 1987; Sallis \& McKenzie, 1991). A PE teacher is faced with the challenge of equipping students with the skills they need to regulate their own exercise behavior (Dishman, Sallis, \& Orenstein, 1985; Sallis, 1987) by means of adequate education and instruction. As a result, $\mathrm{PE}$ is considered to contribute to the establishment and maintenance of a healthy and physically active life-style (Pate, O'Neill, \& Mclver, 2011; Simons-Morton, 1994).

It is uncontroversial that PE teachers teaching styles can influence exercise behavior and physical activity levels outside of the classroom (e.g., Hastie, van der Mars, Layne, \& Wadsworth, 2012; Marsh \& Peart, 1988). A variety of teaching styles have been recommended, ranging from the implementation of only one style (such as directive instruction) to a broad variety of applied options (Joyce \& Weil, 1986; Johnson \& Johnson, 1994; Slavin, 1990). Furthermore, remarkable individual differences between students with regard to their abilities, intelligence (Armstrong, 1994), self-regulation (Zimmerman, 1990), or learning style (Curry, 1999) had been reported. As a consequence, it is indispensable that a teacher acquires and uses different teaching styles adaptively (Bellanca, 1998) in order to meet the needs of all students and to improve their performance (Doolan \& Hongsfeld, 2000).

PE seems to promote students' further interest in physical activity and sports (Standage, Gillison, Ntoumanis, \& Treasure, 2012; Almond \& Harris, 1998) and adolescents showing positive attitudes toward PE are more likely to exercise in their future lives (Ferguson, Yesalis, Pomrehn, \& Kirkpatrick, 1989). In contrast, research has shown that over time, the interest and participation in PE can decrease (Anderssen, 1993; Van Wersch, Trew \& Turner, 1992). Teachers should therefore aim at feedback-related teaching styles focusing on motivation, interest and improvement. Moreover, it is important to emphasize individualized learning and task related instructions that assist efforts towards improvement (Ames, 1992). Teacher styles concerned with a feedback component were linked to providing knowledge, motivation, and reinforcement (Fitts \& Posner, 1967). Accordingly, feedback behavior can operate as a strong source of motivation and as a crucial factor in learning (Cloes, Premuzak, \& Piéron, 1993; Graham, 1992; Sharp, 1992).

Furthermore, adequate teaching behavior can bear a significant impact on the students' level 
of intrinsic motivation (Ryan, Connell, \& Deci, 1985). Motivation in PE, in turn, is linked to a number of important outcomes, such as participation in optional PE (Ntoumanis, 2005) and after-school sports (Goudas, Dermitzaki, \& Bagiatis, 2001). Finally, the students' satisfaction with PE seems to provide the basis for a high and motivated engagement in sports (Carlson, 1995; Graham, Holt-Hale, \& Parker, 1998; Portman, 1995).

It is therefore essential to find an appropriate definition of adequate teaching behavior, to render it assessable and applicable. In this sense, the multidimensional leadership model (see Figure 1; Chelladurai, 1978) can serve as a suitable framework for investigating teaching behavior in PE. This model was originally developed for sports related situations involving a coach as well as a team. More specifically, the model focuses on the individual behavior of the coach. This behavior can be examined according to (a) the requirements of a particular situation, (b) the athletes' preferences for the coaches' behavior and (c) the perception of the coaches' behavior. Several studies show that a congruence between the perception of coaches and athletes regarding leadership behavior leads to higher performance (Serpa, Pataco, \& Santos, 1991; Weiss \& Friedrichs, 1986), and satisfaction of the team members (Dwyer \& Fischer, 1990; Riemer \& Chelladurai, 1995). Further elements have to be considered in addition as the characteristics of the coach, the situation and the team members can all influence leadership behavior (Chelladurai \& Carron, 1983; Chelladurai, Imamura, Yamaguchi, Oinmuma, \& Miyauchi, 1988; Chelladurai, Malloy, Imamura, \& Yamaguchi, 1987).

The multidimensional leadership model is based on leadership theories such as the contingency model of leadership effectiveness (Fiedler, 1967), the path-goal theory of leadership (House \& Dressler, 1974), the adaptive-reactive theory of leadership (Osborn \& Hunt, 1975), and Yukl's (1971) discrepancy model of leadership. Because the transactions among leaders and followers within a particular situational context are of extreme importance for understanding leadership processes (Hollander, 1978), Chelladurai's model focuses on the leader, the followers, and in addition on situational context dimensions of leadership. The multidimensional leadership model distinguishes between situational characteristics (e.g. team goals, team structure, group task and associated technology, social norms etc.), leader characteristics (e.g. personality, ability, experience, etc.), and member characteristics (e.g. gender, age, ability, etc.) as antecedents of leader behavior. Moreover, leader behavior can be classified as required, preferred, or perceived, and the congruence of these three factors influences the levels of performance and satisfaction. The outcome variables performance and satisfaction are considered to be mediated by the required and preferred behavior of the leader. An additional feedback loop is assumed between performance and satisfaction outcomes and perceived leader behavior that in turn eventually influences the perception of the actual behavior. 


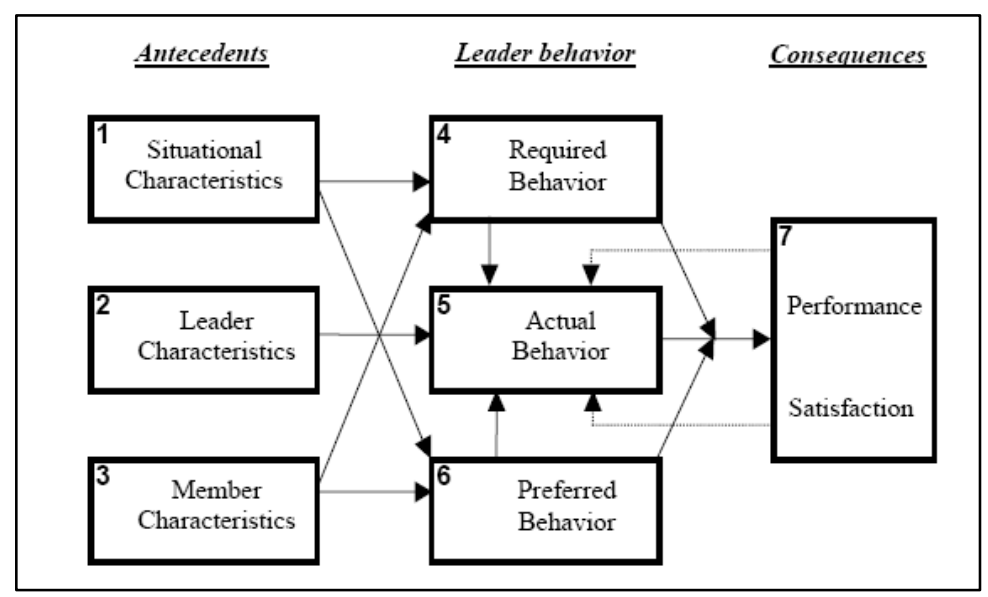

Figure 1. The Multidimensional Model of Leadership for Sport

Chelladurai, P. (1999). Human resource management in sport and recreation. (p.163).

The multidimensional leadership framework has been empirically tested with the Leadership Scale for Sports (LSS; Chelladurai \& Saleh, 1980), a questionnaire assessing different aspects of leadership behavior (for review see Chelladurai, 2012). The LSS consists of five factors: Training and Instruction, Democratic Behavior, Autocratic Behavior, Social Support, and Positive Feedback. Training and Instruction aim at the structure and management of the training session and at the improvement of the athletes' achievement and learning. The opportunity for the athletes to participate in decision-making is termed democratic behavior. On the other hand, autocratic behavior indicates the extent to which a coach emphasizes his or her authority. Social support refers to the involvement of the coach in satisfying the interpersonal needs of the athletes. Finally, positive feedback describes the extent to which the coach compliments the athletes for their performance and contribution. Translated versions of the LSS were successfully implemented and tested in several countries in the field of youth, amateur and professional sport (Chelladurai et al., 1988; Iseberg \& Chelladurai, 1990; Kim, Lee \& Lee, 1990; Iordanoglou, 1990; Altahayneh, Hindawi, \& El-Kilani, 2008; Høigaard, Jones, \& Peters, 2008). Even though the subscale autocratic behavior was not replicated in all studies (Lee, Williams, Cox \& Terry, 1993), the LSS can be classified as an instrument that is both reliable (Riemer \& Chelladurai, 1995; Gardner et al., 1996; Price \& Weiss, 2000; Trail, 2004; Hollembeak \& Amorose, 2005) as well as valid (Iordanoglou, 1990; Isberg \& Chelladurai, 1990; Kim, Lee, \& Lee, 1990; Chelladurai \& Riemer 1998). For the German speaking area a translated four factor version of the LSS (without the dimension of autocratic behavior) was established by Würth, Saborowski, and Alfermann (1999). With regard to the LSS measurement, it is important to note that the instrument exists in three different versions: (1) athletes' perceptions of their coaches' leader behavior, (2) athletes' preferences of their coaches' leader behavior, and (3) coaches' perceptions of their own leader behavior. According to the congruence hypothesis of the multidimensional leadership model 
(Chelladurai, 1978), the concordance of the different LSS versions can be used as a predictor of the athletes' satisfaction and performance (Paradis, \& Loughead, 2012).

The aim of this work was to design an appropriate measurement of PE teacher behavior. To focus the interaction between teacher and students, an instrument was chosen that included the perspectives of both the teachers and their students. Therefore, the LSS was adapted to the PE context and arranged into the three versions: (1) students' preference for specific teacher behaviors, (2) students' perception of their teachers' behavior and the (3) teachers' perception of their own behavior. We had to make sure that all three versions of the instrument satisfied reliability and validity. Another challenge was to examine the influence of the different behavior styles on students' satisfaction and the effect of congruence between the different LSS versions. Finally, a comparative analysis was necessary to reveal which constellation was most successful to predict students' satisfaction. Owing to this proceeding, we aimed to establish a suitable instrument for the assessment of PE teacher behavior. The use of such a measurement might serve as an entrance approach to make teacher behavior in PE tangible. A two-sided assessment of teacher behavior from the students' as well as the teachers' perspective is of focal interest. Moreover, the request of students' preferred teaching behavior further allows for of gaining valuable information concerning the needs of students in PE.

\section{Method}

This research report refers to two independent studies. The first study addressed PE teachers and it was conducted as a nationwide online-survey. In the second study, an extensive questionnaire-based investigation was applied in German grammar schools. The latter study was divided into two sub-studies: Study 2a: Student-Perspective is concerned with the students' perception/students' preference of teaching behavior and Study 2b: Student/Teacher-Perspective regarding students' perception/teachers' perception and students' preference/teachers' perception of teaching behaviour.

\subsection{Participants}

In study 1 a complete dataset of 527 physical education teachers (254 females and 273 males) was obtained. The age of the participants ranged from 21 to 64 with an average of 42.11 years $(\mathrm{SD}=11.21)$. The sample of study $2 \mathrm{a}$ consisted of 1452 students ( 625 females, 798 males and 29 unstated). Their age varied from 9 to 17 with a mean of 13.31 years $(\mathrm{SD}=1.49)$. Finally, the sample of Study 2b consisted of 696 students (374 females, 312 males and 10 unstated) and 18 physical education teachers ( 8 females and 10 males). In this sample, the age differed from 9 to 17 with an average of 13.11 years $(S D=1.54)$ for students and from 28 to 60 years with a mean of 49.87 years $(\mathrm{SD}=14.99)$ for teachers.2.1.1 Heading Level-3

\subsection{Materials}

For this project, the items of the German version of the LSS were rephrased with reference to a school context and transferred to the three versions of teacher perception (LSS-Teacher), students' perception (LSS-Student) and preference (LSS-Preference) of physical education behavior, respectively. The instruments were designed as 21-item questionnaires that 
measured four dimensions of physical education behavior: education and instruction (7 items), democratic behavior (5 items), positive feedback ( 5 items), and social support (4 items). All of the three LSS versions started with the same preface to the individual items. Thus, the LSS-Teacher started with "I show this behavior...", the LSS-Student started with "My teacher..", and the LSS-Preference started with "In physical education classes it is important for me that my teacher...". The items, however, were comparable in all LSS versions. In order to assess the behavior of teachers regarding the enhancement of the students' sportive and social performance, the dimension education and instruction was established (e.g. "Explains to each student the techniques and tactics of the sport"). The second dimension, democratic behavior, focused on behavior that allows students to participate in making decisions on the arrangements of the lesson and other activities (e.g. "Lets the students share in decision making". Positive feedback was the dimension for measuring behavior relating to the reinforcement of students' good performance and behavior (e.g. "Compliments a student on good performance while others are present "). The forth dimension, social support, concentrates on behavior that endeavors to reach and maintain a good relationship with the students and to establish a pleasant classroom climate (e.g. "Helps students with their

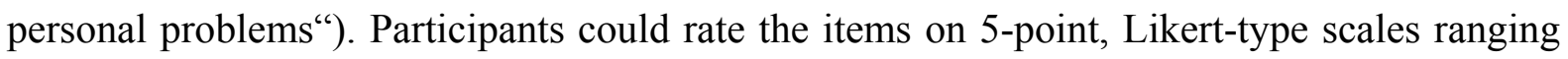
from never (1) to always (5). A high score represented a strong perception of the teachers' behaviour, whereas a low one represented a low perception of their behavior.

A scale of four items was developed in order to assess the satisfaction of students in line with Riemer and Chelladurai, (1995). All items started with the phrase "How satisfied are you with..." and continued with PE related content (e.g. "the structure and the arrangement of the physical education classes?"). Responses were provided on a 7-point, Likert-type scale ranging from not satisfied at all (1) to extremely satisfied (7).

\subsection{Procedure}

For study 1, we applied an online questionnaire to test the LSS-Teacher in a large sample. To measure the importance and adequacy of the LSS-Teacher, control items for each of the four subscales were added. The control items were introduced by the expression "This aspect is important for my physical education classes" and could be rated on a 4-point, Likert-type scale ranging from unimportant (1) to very important (4). For example, a control item for the dimension positive feedback was "direct award and approval of good student performance". A mailing list was composed in order to contact various schools, using a public register of German grammar schools (www.schulweb.de). Moreover, a hyperlink to the online-survey was placed on websites relevant for PE teachers (for example the federation of physical education teachers www.dslv.de and the teacher information platform www.teachersnews.net). In addition, a short description of the project was distributed via e-mail and presented on the websites. The completion of the questionnaire took approximately 10 minutes.

Study 2 addressed secondary level students in German grammar schools. From seven schools 49 classes were recruited in order to obtain a sufficient sample size. The questionnaires were administered in close collaboration with the PE teachers. Following an intensive briefing and the supply of a handout instruction, the cooperating teachers applied the LSS-Perception, the 
LSS-Preference and the satisfaction scale to all classes. Moreover, the participating teachers were asked to fill in the LSS-Teacher form. We were only able to attain a complete dataset for 27 classes so the sample is divided, as mentioned above, into the sub-studies $2 \mathrm{a}$, full sample for LSS-Perception and LSS-Preference and 2b, sub-sample with all of the LSS versions.

\section{Results}

\subsection{Study 1}

\subsubsection{Reliability and descriptive statistics}

The means of the four control items show that all categories can be considered as important for PE. All subscales reached an appropriate level of reliability: the LSS-Teacher dimensions education and instruction and positive feedback were acceptable $(\alpha=.74$ and $\alpha=.78$, respectively) and the dimensions democratic behavior and social support are considered as good ( $\alpha=.84$ and $\alpha=.83$, respectively). According to Kline (1999) $\alpha$-scores between 0.5 and 0.6 can be considered as poor, $\alpha$-scores between 0.6 and 0.7 as questionable, $\alpha$-scores between 0.7 and 0.8 as acceptable, $\alpha$-scores between 0.8 and 0.9 as good and $\alpha$-scores above 0.9 as excellent. Moreover, the mean scores illustrate that most teachers believed the behavioral pattern described by the LSS-Teacher items to occur frequently in their own educational habits.

The four dimensions of the LSS-Teacher were all correlated significant ( $r$ s $>.45$ ). All of the subscales thus seemed to share an overlapping content beyond the aspect that was specifically addressed. This overlap partly seems due to behavior that positively influences and promotes the students' abilities and welfare, so the subscales assumingly have aspects in common (Würth, Saborowski \& Alfermann, 1999). Correlational analyses between the control items and the corresponding LSS-Teacher dimensions were conducted to estimate the importance of the instrument for PE classes. Following our assumption, the control items were related to the distinct subscales. The highest correlation always appeared in conjunction with the matched LSS-Teacher dimension. Hence, the LSS content seems to be suitable for assessing PE contexts.

\subsubsection{Construct Validity}

Chelladurai and Riemer (1998) already confirmed the subscale structure of the LSS with a confirmatory factor analysis. They referred to the fit index RMSEA (root-mean-square error of approximation) as an indicator for the appropriateness of the model. Even though the $\chi^{2}$ goodness of the fit index is widely accepted, it is closely related to the size of a sample, and is not appropriate as a fit index in studies with a large sample size (Marsh, Balla, \& McDonald, 1988). Consequently, the $\chi^{2}$ index does not seem to be appropriate in our study. The applied model $(d f=183)$ reflected the postulated four dimensional structure of the LSS. The software AMOS 7.0 was used for testing the model (Arbuckle, 2006). In agreement with current standards (Hu \& Bentler, 1998; 1999; MacCallum \& Austin, 2000), we determined the goodness of fit by the standardized root-mean-square residual (SRMR) and the root-mean-square error of approximation (RMSEA, Steiger, 1989; Steiger \& Lind, 1980). A SRMR below 0.10 is taken to indicate a good model fit (Quintana \& Maxwell, 1999). Furthermore, a RMSEA below 0.05 is considered to be a very good fit and values between 
0.06 and 0.08 are regarded as a good fit (Browne \& Cudeck, 1993; MacCallum et al., 1996). In line with the aforementioned indices the model proved to be a good fit to the data of our study $(\mathrm{SRMR}=0.07$ and $\mathrm{RMSEA}=0.07$, respectively). The examination of the model's parameters showed that all item loadings on the four assigned factors were significant, positive, and exceeded the conventionally defined minimum of .40 (Ford, McCallum, \& Tait, 1986). The standardised loadings ranged from .50 to .83 . Based on these findings, it seems reasonable to apply the LSS to PE settings.

\subsection{Study 2}

\subsubsection{Reliability and descriptive statistics}

The reliability was good for all of the LSS-Student scales and LSS-Preference ( $\alpha$ ranged from .81 to .87) and acceptable for the LSS-Teacher scale ( $\alpha$ ranged from .65 to .83). The examination of the mean scores revealed that students required more teacher behavior in all domains but social support. In general, students perceived and mostly desired a moderate or high level of the specific teacher behavior. Interestingly, the mean scores of teachers' perception of their own behavior were higher than the perception scores of the students. The teachers' self-rated behavior values exceeded the students' preference values in all of the subscales but for the scale of democratic behavior. Finally, students' satisfaction seemed to be moderate to high.

Correlations of the three LSS versions and the students' satisfaction are described in the following. As mentioned in study 1 the LSS items seem to share common aspects. Consequently, significant positive correlations were observed for the LSS-Student $(r>0.68)$, LSS-Preference $(r>.66)$, and LSS-Teacher $(r>.26)$. The subscale social support of the LSS-Teacher, however, was not correlated with the subscale democratic behavior. The students' perception and their preference of teacher behavior were also positively correlated. In contrast, the teachers' perception of their own behavior was unrelated to the preference of the students, although it was correlated to their perception. Overall, the students' satisfaction was almost always associated with all variables. As an exception, the LSS-Teacher subscale social support bore no correlation with the satisfaction of the students.

\subsubsection{Construct Validity}

For the LSS-Student and the LSS-Preference a confirmatory factor analysis was applied. Both models showed an acceptable fit to the data: SRMR $=0.06$ and RMSEA $=0.08$ for LSS-Student $(d f=183)$ and SRMR $=0.05$ and RMSEA $=0.08$ for LSS-Preference $(d f=183)$. According to reliability scores the instruments can be considered as reliable and valid.

\subsection{Study 2a: Student-Perspective}

The sample for study 2a included all participating students because all of the administered LSS-Students and LSS-Preference questionnaires were filled in. Hierarchical multiple regression analyses (HMRA) were conducted to examine the predicting effects of the LSS. Table 1 presents an overview of the four HMRAs concerning all subscales of the LSS-Preference, LSS-Student and LSS-Interaction (LSS-Preference X LSS-Student). Each 
HMRA included three steps: the students' preference was entered first (step 1) followed by the addition of the students' perception (step 2) and finally the interaction term was included (step 3). We chose these predictors since we assumed that the LSS-Preference would allow for predicting students' satisfaction and that the LSS-Student served as a stronger predictor.

Table 1. Predicting Students' Satisfaction by the LSS- Preference and LSS- Student - Study $2 \mathrm{a}$

\begin{tabular}{|c|c|c|c|c|c|c|}
\hline Step & Variable & $\mathrm{B}$ & $\mathrm{R}^{2}$ & $\mathrm{R}^{2}$ change & $F$ change & $F$ \\
\hline \multicolumn{7}{|c|}{ LSS-Preference $(P) \&$ LSS-Student } \\
\hline 1 & LSS-P Instruction & $.24 * * *$ & 0.05 & 0.05 & $85.03 * * *$ & $85.03 * * *$ \\
\hline \multirow[t]{2}{*}{2} & LSS-P Instruction & .01 & 0.34 & 0.28 & $593.51 * * *$ & $357.84 * * *$ \\
\hline & LSS-S Instruction & $.58 * * *$ & & & & \\
\hline \multirow[t]{3}{*}{3} & LSS-P Instruction & .03 & 0.35 & 0.00 & $9.46^{* *}$ & $243.20 * *$ \\
\hline & LSS-S Instruction & $.57 * * *$ & & & & \\
\hline & LSS-P x LSS-S Instruction & $.07 * *$ & & & & \\
\hline 1 & LSS-P Democratic & $.18 * * *$ & 0.03 & 0.03 & $48.61 * * *$ & $48.61 * * *$ \\
\hline \multirow[t]{2}{*}{2} & LSS-P Democratic & .02 & 0.31 & 0.28 & $561.76 * * *$ & $315.25 * * *$ \\
\hline & LSS-S Democratic & $.55 * * *$ & & & & \\
\hline \multirow[t]{3}{*}{3} & LSS-P Democratic & .36 & 0.31 & 0.00 & 2.38 & $211.17 * * *$ \\
\hline & LSS-S Democratic & $.54 * * *$ & & & & \\
\hline & LSS-P x LSS-S Democratic & .03 & & & & \\
\hline 1 & LSS-P Positive Feedback & $.20 * * *$ & 0.04 & 0.04 & $62.00 * * *$ & $62.00 * * *$ \\
\hline \multirow[t]{2}{*}{2} & LSS-P Positive Feedback & .01 & 0.26 & 0.21 & $401.357 * *$ & $240.86 * * *$ \\
\hline & LSS-S Positive Feedback & $.50 * * *$ & & & $*$ & \\
\hline \multirow[t]{3}{*}{3} & LSS-P Positive Feedback & .04 & 0.26 & 0.00 & $9.91 * *$ & $164.94 * * *$ \\
\hline & LSS-S Positive Feedback & $.49 * * *$ & & & & \\
\hline & LSS-P x LSS-S P. Feedback & $.07 * *$ & & & & \\
\hline 1 & LSS-P Social Support & $.22 * * *$ & 0.04 & 0.04 & $70.14^{* * *}$ & $70.14 * * *$ \\
\hline \multirow[t]{2}{*}{2} & LSS-P Social Support & -.09 & 0.32 & 0.27 & $546.36 * * *$ & $322.37 * * *$ \\
\hline & LSS-S Social Support & $.57 * * *$ & & & & \\
\hline \multirow[t]{4}{*}{3} & LSS-P Social Support & .00 & 0.32 & 0.00 & 2.01 & $215.75 * * *$ \\
\hline & LSS-S Social Support & $.56 * * *$ & & & & \\
\hline & LSS-P $\quad x \quad$ LSS-S $\quad$ Social & .33 & & & & \\
\hline & Support & & & & & \\
\hline
\end{tabular}

$* \mathrm{p}<0.05, * * \mathrm{p}<0.01, * * * \mathrm{p}<0.001$

Moreover, the interaction term was entered in order to examine concurrent effects of the LSS-Preference and LSS-Student.

The LSS-Preference subscales all had a significant influence on students' satisfaction ( $\beta$ 
ranging from .18 to .24). The explained variance ranged at a low level ( $3 \%$ to $5 \%)$. Once the LSS-Student was included, LSS-Preference was no longer predictive. Hence, the effect seemed to be mediated by the LSS-Student ( $\beta$ ranging from .50 to .58). Furthermore, at step 2 the explained variance ranged from $26 \%$ to $34 \%$. The interaction term, added in step 3 , was significant for the subscales of education and instruction and positive feedback. According to Riemer and Chelladurai (1995) the significance of the interaction term but not the size of the change in $R^{2}$ is important. They refer to McFarlin and Rice (1991) who stated that, "The critical point, however, is not how much variance is explained but whether the increment provided by the interaction term is statistically reliable" (p.34).

\subsection{Study 2b: Student/Teacher-Perspective}

Since it was not possible to gain a complete dataset for all versions of the LSS, study $2 b$ included only those data of students that could be combined with self-description data of their PE teachers from the LSS-Teacher assessment. For study $2 \mathrm{~b}$ eight HMRAs were conducted: four concerning the teacher and the student perception, and four focusing on student preference and teacher perception. In analogy to the data analysis reported for study $2 \mathrm{a}$, the LSS-Teacher scores were entered first (step 1), followed by the LSS-Student (step 2), presumably the more powerful predictor. Finally, the interaction term (LSS-Teacher $\mathrm{x}$ LSS-Student) was included (step 3). As shown in Table 2, all of the LSS subscales - Teacher revealed a significant influence on students' satisfaction ( $\beta$ ranging from -.07 to .30). Explained variance ranged at a low level from $<1 \%$ to $9 \%$. The inclusion of the LSS-Student enhanced the explained variance (ranging from $32 \%$ up to $41 \%$ ). Interestingly, the LSS-Teacher remained significant at step 2 ( $\beta$ ranging from -.13 to .20) but seemed to be partly mediated by the LSS-Student ( $\beta$ ranging from .49 to .61 ). The interaction term added at step 3 did not increase the explained variance and it was not significant for any subscales.

In consistency with the procedure used before, the LSS-Preference was entered first (step 1), followed by the LSS-Teacher (step 2) that was considered to be the stronger predictor. In a final step, the interaction term (LSS- Preference x LSS- Teacher) was inserted (step 3). Table 2 indicates that all the LSS- Preference subscales have a significant influence on students' satisfaction ( $\beta$ ranging from .18 to .25). Explained variance ranged at a low level from $3 \%$ to $6 \%$. The added LSS-Teacher improved the explained variance (ranging from $7 \%$ up to $13 \%$ ). Moreover, the LSS- Preference and LSS-Teacher were both significant at step 2 ( $\beta$ ranging from .17 to .25 , and -.08 to .30 , respectively) and appeared to have an equally strong influence on students' satisfaction. Finally, the interaction term entered in step 3 again revealed to be significant for the subscales education and instruction and positive feedback. 
Table 2. Predicting Students' Satisfaction by the LSS-Teacher, LSS-Student and LSS-Preference - Study $2 b$

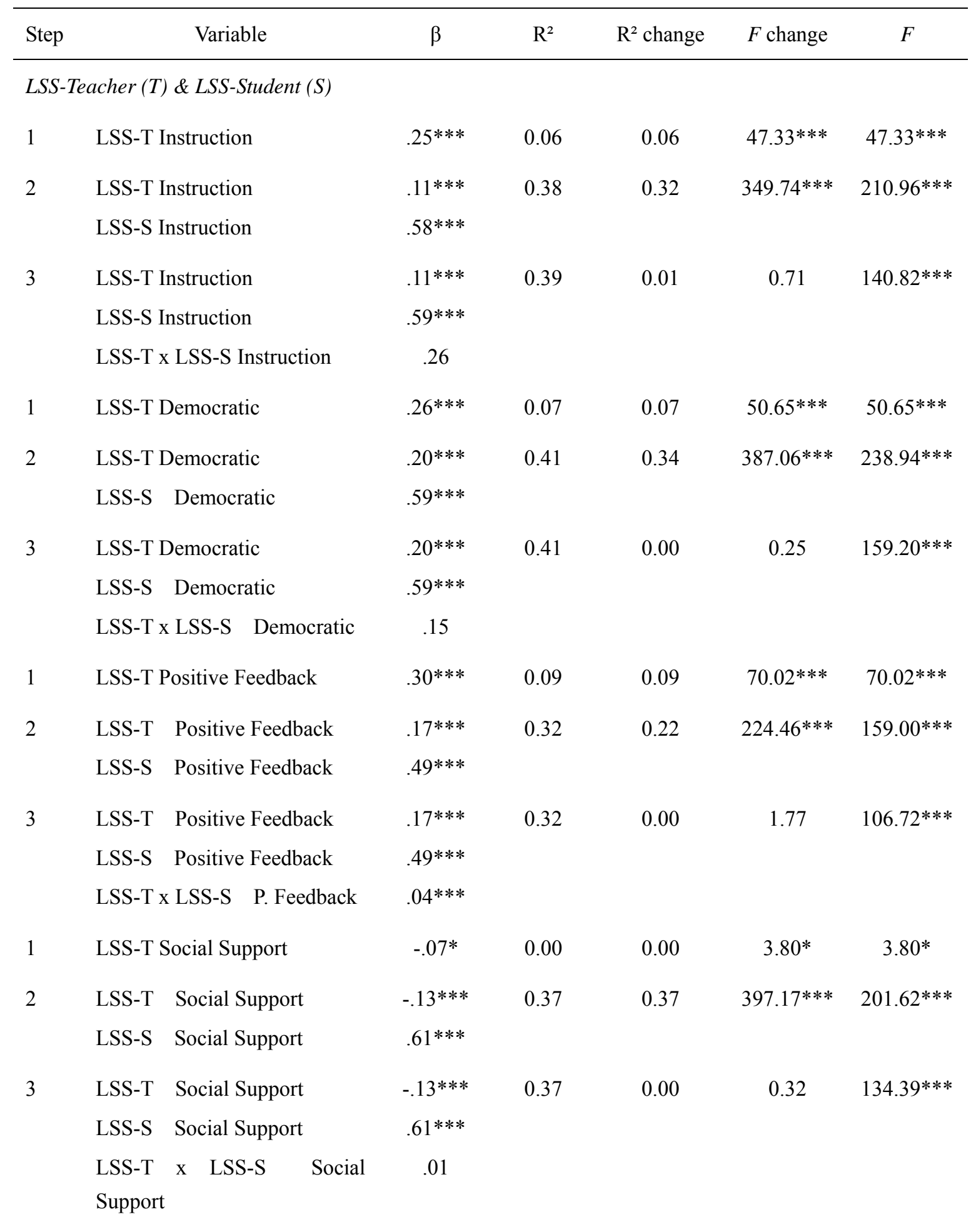

LSS- Preference \& LSS-Teacher

$1 \quad$ LSS-P Instruction

0.06

$45.73 * * *$

$45.73 * * *$ 


\begin{tabular}{|c|c|c|c|c|c|c|}
\hline \multirow[t]{2}{*}{2} & LSS-P Instruction & $.25^{* * *}$ & 0.13 & 0.06 & $50.78 * * *$ & $49.98 * * *$ \\
\hline & LSS-T Instruction & $.25 * * *$ & & & & \\
\hline \multirow[t]{3}{*}{3} & LSS-P Instruction & $.25^{* * *}$ & 0.14 & 0.00 & $5.84 * *$ & $35.51 * * *$ \\
\hline & LSS-T Instruction & $.25^{* * *}$ & & & & \\
\hline & LSS-P x LSS-T Instruction & $.08^{* *}$ & & & & \\
\hline 1 & LSS-P Democratic & $.18 * * *$ & 0.03 & 0.03 & $23.35 * * *$ & $23.35^{* * *}$ \\
\hline \multirow[t]{2}{*}{2} & LSS-P Democratic & $.17 * * *$ & 0.09 & 0.06 & $46.14 * * *$ & $35.55^{* * *}$ \\
\hline & LSS-T Democratic & $.25 * * *$ & & & & \\
\hline \multirow[t]{3}{*}{3} & LSS-P Democratic & $.17 * * *$ & 0.10 & 0.00 & 1.74 & $24.31 * * *$ \\
\hline & LSS-T Democratic & $.25 * * *$ & & & & \\
\hline & LSS-P x LSS-T Democratic & .04 & & & & \\
\hline 1 & LSS-P Positive Feedback & $.18^{* * *}$ & 0.03 & 0.03 & $22.69 * * *$ & $22.69 * * *$ \\
\hline \multirow[t]{2}{*}{2} & LSS-P Positive Feedback & $.17 * * *$ & 0.12 & 0.09 & $68.62 * * *$ & $46.83 * * *$ \\
\hline & LSS-T Positive Feedback & $.30 * * *$ & & & & \\
\hline \multirow[t]{3}{*}{3} & LSS-P Positive Feedback & $.17 * * *$ & 0.13 & 0.01 & $7.62 * *$ & $34.08 * * *$ \\
\hline & LSS-T Positive Feedback & $.29 * * *$ & & & & \\
\hline & LSS-P x LSS-T P. Feedback & $.10^{* *}$ & & & & \\
\hline 1 & LSS-P Social Support & $.25 * * *$ & 0.06 & 0.06 & $44.07 * * *$ & $44.07 * * *$ \\
\hline \multirow[t]{2}{*}{2} & LSS-P Social Support & $.25 * * *$ & 0.07 & 0.00 & $4.77^{*}$ & $24.55^{* * *}$ \\
\hline & LSS-T Social Support & $-.08 *$ & & & & \\
\hline \multirow[t]{3}{*}{3} & LSS-P Social Support & $.25^{* * *}$ & 0.07 & 0.00 & 0.41 & $16.49 * * *$ \\
\hline & LSS-T Social Support & $-.08^{*}$ & & & & \\
\hline & LSS-P $\quad x \quad$ LSS-T $\quad$ Social & .02 & & & & \\
\hline
\end{tabular}

${ }^{*} \mathrm{p}<0.05,{ }^{* *} \mathrm{p}<0.01,{ }^{* * *} \mathrm{p}<0.001$

\section{Discussion}

The purpose of this study was to explore whether the Leadership Scale for Sports (LSS) is a suitable instrument to measure teacher behavior when considering the perspectives of students and teachers, respectively, in physical education (PE). We were further interested in the impact of different teaching styles on students' satisfaction. We were moreover interested in finding out which version of the instrument might prove best at predicting students' satisfaction. Finally, we examined the interaction of the different LSS versions and its impact on students' satisfaction according to the congruence hypothesis of the multidimensional 
leadership model (Chelladurai, 1978).

\subsection{Reliability and Validity of the LSS}

The presented confirmatory factor analysis as well as the reliability coefficients revealed that all three LSS versions seem adequate for the use in school contexts to assess teaching behavior that can influence the students' satisfaction. Since teachers judged the contents of the LSS subscale as important a kind of face validity can be attributed to the LSS with regard to PE.

\subsection{Prediction of students' satisfaction by the three LSS versions}

The applied HMRAs and the correlations showed that all versions of the LSS and all subscales substantially contribute to the students' satisfaction. Since we analyzed combined effects of the LSS versions in study 2, a closer inspection of the predictive power was possible. In general, the students' perception of the teacher behavior (LSS-Student) emerged as the strongest factor influencing students' satisfaction followed by the teachers' perception of their own behavior (LSS-Teacher). Finally, the students' preference of a specific teacher behavior (LSS-Preference) seemed to bear the least impact on students' satisfaction and its influence is largely mediated by the LSS-Student factor. The perception of actual teacher behavior therefore outperformed the description of preferred teacher behavior in predicting students' satisfaction. This predictive superiority of LSS-Teacher holds also true in relation to the LSS-Student. However, when LSS-Preference and LSS-Teacher were regarded in combination, their influence on students' satisfaction was comparable. Accordingly, among all versions and all subscales of the LSS, the LSS-Student appeared to be the most important instrument for predicting the satisfaction of students in PE.

\subsection{Examination of the interaction effects - congruence hypothesis}

As mentioned earlier, the congruence hypothesis is crucial to the multidimensional leadership model (Chelladurai, 1978). Therefore, we entered an interaction term in the last step of the applied HMRAs. For study 2a the interaction was significant in cases of the subscales education and instruction and positive feedback. Low and high scores of the LSS-Student and LSS-Preference were plotted in order to interpret these interactions. The constitution of the interactions is illustrated in Figure 2, exemplary for the factor positive feedback. 


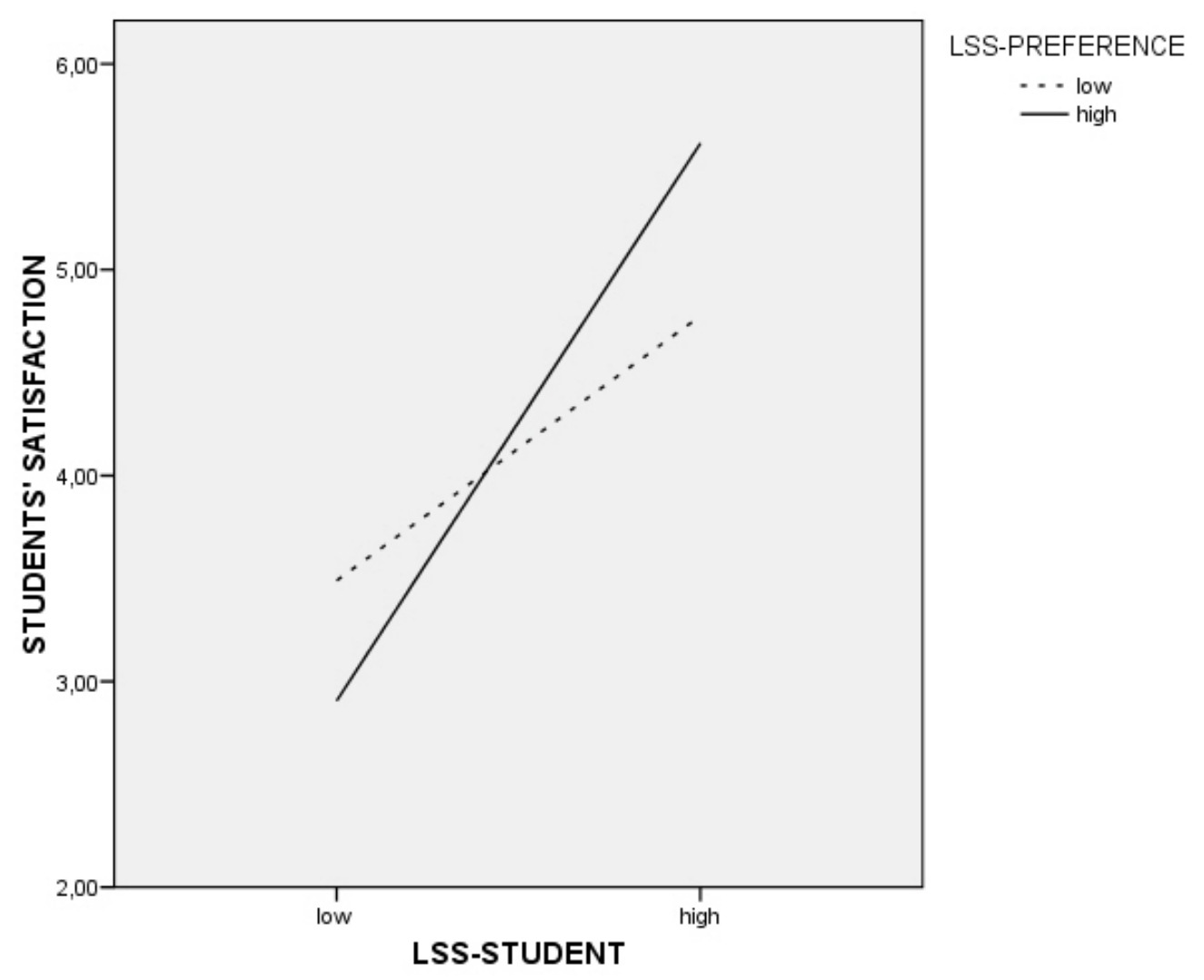

Figure 2. Interaction of LSS-Student and LSS-Preference

When considering the disordinal interaction displayed here, the satisfaction of students with a preference for a high rate of positive feedback was apparently negatively affected if they perceived their teachers as diverging from their own needs. Students, however, who had a preference for a low rate of positive feedback benefited from a perceived teacher behavior showing more positive feedback. In summary, students perceiving low positive feedback were less dissatisfied than the students who required a high level of that behavior. This indicates a slight congruence effect, too.

Figure 3 demonstrates the interactions found in study $2 \mathrm{~b}$ again for positive feedback. For a better understanding, the low and high scores of the LSS-Teacher and LSS-Preference were plotted. Considering the displayed ordinal interaction it is evident that among all students, satisfaction was higher when the teachers perceived their own behavior as equally high. Those students, however, who preferred a low positive feedback were generally less satisfied. In contrast, students who preferred a high level of positive feedback benefit from a fit-constellation with their teachers' self-description. In addition, the latter students' satisfaction was negatively affected by an incongruous student-teacher constellation. In this respect, the congruence hypothesis was confirmed since only students, which were in accordance with their teachers, were more satisfied. 


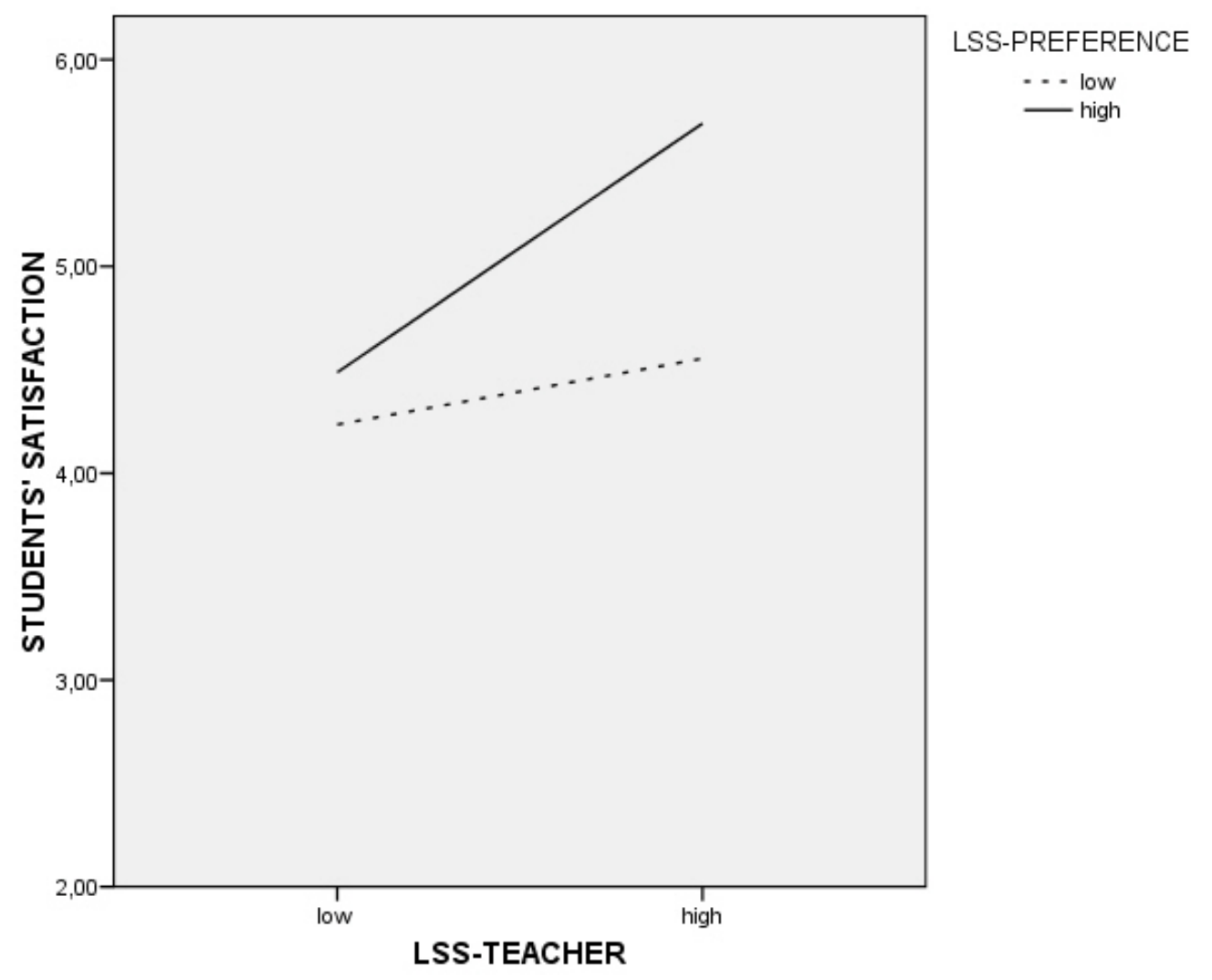

Figure 3. Interaction of LSS-Teacher and LSS-Preference

\subsection{Further perspectives - congruence hypothesis}

With regard to the congruence hypothesis, there is an ongoing discussion about the best way of analyzing the fit-constellation. As Johns (1981) criticized discrepancy scores for being unreliable, we conducted HMRAs with interaction terms to avoid inaccuracy measures here. So far, only a few studies have used this kind of analysis and when they did so, the results were not consistent (Riemer \& Chelladurai, 1995; Riemer \& Toon, 2001). Nonetheless, our findings encourage the idea that the applied approach constituted both an appropriate and a successful way of analyzing the data.

The interaction effects found in study $2 \mathrm{a}$ and $2 \mathrm{~b}$ are restricted to the subscales education and instruction and positive feedback. These dimensions of the LSS seem to bear the most important influence on students' satisfaction regarding fit-constellations between the perception and preference of teaching behavior. Clearly, students who preferred and perceived a high level of that kind of teaching behavior were generally more satisfied, whereas students who preferred a low level of that behavior were generally less satisfied. A possible explanation could be that those students were also less interested in PE. In our study, we measured interest by a 14-item questionnaire based on the procedures also used by 
Thomas (1987) and Wigfield et al. (1997). We found a correlation between satisfaction and interest $(r=.51)$. Hence, students who displayed low scores in the subscales education and instruction and positive feedback presumably attached little importance to PE in general.

\subsection{General discussion}

The aforementioned results are consistent with other findings regarding leadership in sports (for a detailed overview: Chelladurai, 1990; Chelladurai 2007). Alfermann and Würth (2005) considering the dimensions of instruction and feedback as important coach behaviors bearing a positive impact on athletes and their satisfaction. This is also in line with the results established by Chelladurai and Riemer (1998) as well as those of Smith and Smoll (1996) who analyzed the influence of perceived coach behavior on athletes' satisfaction. Furthermore, other studies reported that leadership behavior-congruency is related to satisfaction (Chelladurai, 1984; Horne \& Carron, 1985; Riemer \& Chelladurai, 1995). There is additional emphasis that a leader (coach or teacher) has to be active in the role of providing instruction and guidance (Pescosolido, 2001) and that a leader has to ensure that the needs of the entrusted persons (students) are satisfied and that their objectives can be reached (Carron \& Hausenblas, 1998). Accordingly, the LSS dimensions of education and instruction and positive feedback represent behavior that is concerned with the enhancement of students' sportive and social performance and the reinforcement of students' good performance and behavior. Several researchers (Allen \& Howe, 1998; Black \& Weiss, 1992) emphasized that coaches who frequently provide positive and encouraging feedback enhance the development of intrinsic motivation in their athletes. Moreover, Weiss (1987) and Feltz (1988) note that it is important for a teacher to enable students to develop positive attitudes regarding their progress in PE for improving the students' intrinsic motivation. Athletes who perceived their coaches to show a high frequency of positive feedback felt more competent and were more interested in, and satisfied with, sports (Amorose \& Horn, 2000). As a consequence, constantly perceived success in sport related situations will lead to a high level of satisfaction and increased self-esteem (Mitchell, 1996). In contrast, the perception of failure causes a lack of intrinsic motivation, whereas the continuing feeling of success increases the intrinsic motivation of students (Bandura \& Schunk, 1981). The motivation of students for PE is highly related to beneficial outcomes, such as participation in voluntary sports groups and recreational exercises and sports (Goudas et al., 2001; Ntoumanis, 2005). Therefore, students' satisfaction with PE can lead to a long-term motivation and engagement in sports and exercise outside school (Carlson, 1995; Graham et al., 1998; Portman, 1995; Siedentop, 1991). Satisfaction can therefore potentially help students establish and maintain a healthy and physically active life-style (Simons-Morton, 1994; Fairclough \& Stratton, 2005; Standage, Duda, \& Ntoumanis, 2005).

\subsection{Conclusion}

In summary, our findings provided evidence for the adequateness of the assumption that the LSS is a suitable instrument for measuring PE-related teaching behavior that can influence students' satisfaction. Moreover, we found that the students' perception of their teachers' behavior highly influences students' satisfaction. With regard to student-teacher congruence, 
education and instruction and positive feedback seem to be the most important behavior styles. Thus, teachers should provide these behaviors in an appropriate way to adapt to the needs of theirs students. It is nevertheless important to promote students interests in PE and physical activities in general to establish a profound basis for the physical education of students' physical behavior.

\section{Acknowledgements}

We would like to thank all the participating students and teachers. Moreover, we are grateful to our student assistants for their help with data collection and analysis.

\section{References}

Aarø.L.E., Wold.B., Kannas.L. \& Rimpala.M. (1986) Health behaviour in schoolchildren. A WHO cross-national survey. A presentation of philosophy, methods and selected results of the first survey. Health Promotion, 1, 17-33. http://dx.doi.org/10.1093/heapro/1.1.17

Alfermann, D., Lee, M. J. \& Würth, S. (2005). Perceived leadership behavior and motivational climate as antecedents of adolescent athletes' skill development. Athletic Insight [On-line serial], 7 (2).

Allen, J. B., \& Howe, B. L. (1998). Player ability, coach feedback, and female adolescent athletes' perceived competence and satisfaction. Journal of Sport and Exercise Psychology, 20, 280-299.

Almond, L., \& Harris, J. (1998). Interventions to promote health-related physical education. In S. Biddle, J. Sallis, \& N. Cavill (Eds.), Young and active? Young people and health enhancing physical activity: Evidence and implications (pp. 133-149). London: Health Education.

Altahayneh, Z., Hindawi, O., \& El-Kilani, G. (2008). Coaches' leadership behavior as perceived by basketball players in Jordan and its effect on their satisfaction. Dirasat: Educational Sciences, 35(1), 1-13.

Ames, C. (1992). Classrooms: Goals, structures, and student motivation. Journal of Educational Psychology, 84, 261-271. http://dx.doi.org/10.1037/0022-0663.84.3.261

Amorose, A. J., \& Horn, T. S. (2000). Intrinsic motivation: Relationships with collegiate athletes gender, scholarship status and perceptions of their coaches' behavior. Journal of Sport \& Exercise Psychology, 22, 63-84.

Anderssen, N. (1993). Perception of physical education classes among young adolescents: Do physical education classes provide equal opportunities to all students? Health Education Research, 8, 167-179. http://dx.doi.org/10.1093/her/8.2.167

Arbuckle, J. L. (2006). Amos 7.0 user's guide. Chicago: SPSS.

Armstrong, T. (1994). Multiple intelligences in the classroom. Alexandria, VA: Association for Supervision and Curriculum Development. 
Bandura, A., \& Schunk, D. H. (1981). Cultivating competence, self-efficacy, and intrinsic interest through proximal self-motivation. Journal of Personality and Social Psychology, 41, 586-598. http://dx.doi.org/10.1037/0022-3514.41.3.586

Bellanca, J. (1998). Teaching for intelligence: In search of best practices. Phi Delta Kappan, 79, 658-660.

Biddle, S. J. H. (2001). Enhancing motivation in physical education. In G. C. Roberts (Ed.), Advances in motivation in sport and exercise (pp. 101-128). Champaign, IL: Human Kinetics.

Black, S. J., \& Weiss, M. R. (1992). The relationship among perceived coaching behaviors, perceptions of ability, and motivation in competitive age-group swimmers. Journal of Sport and Exercise Psychology, 14, 309-325.

Browne, M. W., \& Cudeck, R. (1993). Alternative ways of assessing model fit. In K. A. Bollen \& J. S. Long (Eds.), Testing structural equation models (pp. 136-162). Newbury Park, CA: Sage.

Carlson. T.B. (1995). We hate gym: Student alienation from physical education. Journal for Teaching in Physical Education, 14, 467-477.

Carron, A. V., \& Hausenblas, H. A. (1998). Group dynamics in sport (2nd ed.). Morgantown, WV: Fitness Information Technology.

Chelladurai, P. (1978). A contingency model of leadership in athletics. Unpublished doctoral dissertation, University of Waterloo, Canada.

Chelladurai, P. (1984). Discrepancy between preferences and perceptions of leadership behaviour and satisfaction of athletes in varying sports. Journal of Sport Psychology, 6, $27-41$.

Chelladurai, P. (1990). Leadership in sport: A review. International Journal of Sport Psychology, Vol. 21, 328-354.

Chelladurai, P (2007). Leadership in sports. In: Handbook of sport psychology pp. 113-135. [Chapter 5] (3rd Ed.). Tenenbaum, Gershon; Eklund, Robert C.; Hoboken, NJ, US: John Wiley \& Sons Inc.

Chelladurai, P. (2012). Models and measurement of leadership in sport. In G. Tenenbaum, R. C. Eklund, A. Kamata (Eds.), Measurement in sport and exercise psychology (pp. 433-442). Champaign, IL US: Human Kinetics.

Chelladurai, P., \& Carron, A. V. (1978). Leadership. Ottawa: Canadian Association for Health, Physical Education and Recreation (Sociology of Sport Monograph Series).

Chelladurai, P., \& Carron, A. V. (1983). Athletic maturity and preferred leadership. Journal of Sport Psychology, 5, 371-380.

Chelladurai, P., Malloy, D., Imamura, H., \& Yamaguchi, Y. (1987). A cross-cultural study of 
preferred leadership in sports. Canadian Journal of Applied Sport Sciences, 12, 106110.

Chelladurai, P., Imamura, H., Yamaguchi, Y., Oinuma, Y., \& Miyauchi, T. (1988). Sport leadership in a cross- national setting: The case of Japanese and Canadian university athletes. Journal of Sport and Exercise Psychology, 10, 374-389.

Chelladurai, P., \& Riemer, H. A. (1998). Measurement of leadership in sport. In J.L. Duda (Ed.), Advances in sport and exercise psychology measurement (pp. 227-253). Morgantown, WV: Fitness Information Technology, Inc.

Chelladurai, P., \& Saleh, S. D. (1978). Preferred leadership in sports. Canadian Journal of Applied Sport Sciences, 3, 85-92.

Chelladurai, P., \& Saleh, S. D. (1980). Dimensions of leader behavior in sports: Development of a leadership scale. Journal of Sport Psychology, 2, 34-45.

Cloes, M., Premuzak, J., \& Piéron, M. (1993). Effectiveness of a video training programme used to improve error identification and feedback processes by physical education teachers. International Journal of Physical Education, 32(3), 4-9.

Curry, L. (1999). Cognitive and learning styles in medical education. Academic Medicine, 74, 409-413. http://dx.doi.org/10.1097/00001888-199904000-00037

Dishman.R.K., Sallis, J.F. and Orenstein.D.R. (1985) The determinants of physical activity and exercise. Public Health Reports, 100, 158-171

Doolan, L. S., \& Hongsfeld, A. (2000). Illuminating the new standards with learning style: striking a perfect match. The Clearing House, 73, 274-278. http://dx.doi.org/10.1080/00098650009600968

Dwyer, J. M., \& Fischer, D. G. (1990). Wrestlers' perceptions of coaches' leadership as predictors of satisfaction with leadership. Perceptual and Motor Skills, 71, 511-517.

Fairclough, S., \& Stratton, G. (2005). 'Physical education makes you fit and healthy'. Physical education's contribution to young people's physical activity levels. Health education research, 20(1), 14-23. http://dx.doi.org /10.1093/her/cyg101

Feltz, D. L. (1988). Self-confidence and sports performance. Exercise and Sport Sciences Reviews, 16, 423-457. http://dx.doi.org/10.1249/00003677-198800160-00016

Ferguson,K.J., Yesalis.C.E., Pomrehn,P.R. \& Kirkpatrick,M.B. (1989) Attitudes, knowledge, and beliefs as predictors of exercise intent and behavior in school children. Journal of School Health, 59, 112-115. http://dx.doi.org/10.1111/j.1746-1561.1989.tb04675.x

Fiedler, F. E. (1967). A theory of leadership effectiveness. New York: McGraw-Hill.

Fitts, P., \& Posner, M. (1967). Human performance. Belmont, CA: Brooks/Cole.

Ford, J., McCallum, R., \& Tait, M. (1986). The application of factor analysis in psychology: A critical review and analysis. Personnel Psychology, 39, 291-314. 
http://dx.doi.org/10.1111/j.1744-6570.1986.tb00583.x

Gardner, D.E., Shields, D.L., Bredemeier, B.J., \& Bostrom, A. (1996). The relationship between perceived coaching behaviours and team cohesion baseball and softball players. The Sport Psychologist, 10, 367-381.

Gee.M. (1987) School physical education: cross-national issues to be researched. In Haag,H., Kayser.D. and Bermet,B.L. (eds), Comparative physical education and eport. Human Kinetics, Champain, IL, Vol. 4, pp. 139-147.

Goudas, M., Dermitzaki, I., \& Bagiatis, K. (2001). Motivation in physical education is correlated with participation in sport after school. Psychological Reports, 88, 491-496. http://dx.doi.org/10.2466/pr0.2001.88.2.491

Graham, G. (1992). Teaching children physical education: Becoming a master teacher. Champaign, IL: Human Kinetics.

Graham G., Holt-Hale. S.A., \& Parker. M. (1998). Children moving: A reflective approach to teaching physical education (4th ed.). Mountain View, CA: Mayfield.

Hagger, M. S., Chatzisarantis, N. L., Culverhouse, T., \& Biddle, S. J. (2003). The processes by which perceived autonomy support in physical education promotes leisure-time physical activity intentions and behavior: A trans-contextual model. Journal of Educational Psychology, 95, 784-795. http://dx.doi.org/10.1037/0022-0663.95.4.784

Hastie, P., van der Mars, H., Layne, T., \& Wadsworth, D. (2012). The Effects of Prompts and a Group- Oriented Contingency on Out-of-School Physical Activity in Elementary School-Aged Students. Journal Of Teaching In Physical Education, 31(2), 131-145.

Høigaard, R., Jones, G. W., \& Peters, D. M. (2008). Preferred coach leadership behaviour in elite soccer in relation to success and failure. International Journal of Sports Science \& Coaching, 3(2), 241-250. http://dx.doi.org/10.1260/174795408785100581

Hollander, E. P. (1978). Leadership dynamics. New York: Free Press.

Hollembeak, J., \& Amorose, A. J. (2005). Perceived coaching behaviors and college athletes' intrinsic motivation: A test of self-determination theory. Journal of Applied Sport Psychology, 17, 20-36. http://dx.doi.org/10.1080/10413200590907540

House, R. J. \& Dressler, G. (1974). A path-goal theory of leadership. In J. G. Hunt \& L. L. Larson (Eds.), Contingency Approaches to Leadership (pp. 29-55). Carbondale, IL: Southern Illinois University Press.

Horne, T., \& Carron, A. V. (1985). Compatibility in coach-athlete relationships. Journal of Sport Psychology, 7, 137-149.

Hu, L., \& Bentler, P. M. (1998). Fit indices in covariance structure modeling: Sensitivity to underparameterized model misspecification. Psychological Methods, 3, 424-453. http://dx.doi.org/10.1037/1082-989X.3.4.424 
Hu, L., \& Bentler, P. M. (1999). Cutoff criteria for fit indexes in covariance structure analysis: indexes in covariance structure analysis: Conventional criteria versus new alternatives. $\quad$ Structural Equation $\quad$ Modeling, $\quad 6, \quad$ 1-55. http://dx.doi.org/10.1080/10705519909540118

Jessor.R. (1984) Adolescent development and behavioral health. In Matarazzo J.D., Weiss.S.M., Herd, J.A., Miller.N.E. and Weiss.S.M. (eds), A handbook of health enhancement and disease prevention. Wiley, New York.

Johns, G. (1981). Difference score measures of organizational behavior variables: A critique. Organizational Behavior and Human Performance, 27, 443-463. http://dx.doi.org/10.1016/0030-5073(81)90033-7

Johnson, D. W., \& Johnson, R. T. (1994). Learning together and along: Cooperative, competitive, and individualistic learning. (4th ed). Boston, MA: Allyn \& Bacon.

Joyce, B., \& Weil, M. (1986). Models of teaching. (3rd ed). Englewood Cliffs, NJ: Prentice-Hall.

Kline, P. (1999). The handbook of psychological testing (2nd ed.). London: Routledge Lee, M., Williams, V., Cox, S.-A. \& Terry, P. (1993). The leadership scale for sport. A Modification for use with British children. Paper submitted for the International Pre-Olympic Congress on Sport Medicine and Sports Sciences. Lillehammer, Norway.

MacCallum, R. C., \& Austin, J. T. (2000). Applications of structural equation modeling in psychological research. Annual Review of Psychology, 51, 201-226. http://dx.doi.org/10.1146/annurev.psych.51.1.201

MacCallum, R. C., Browne, M. W., \& Sugawara, H. M. (1996). Power analysis and determination of sample size for covariance structure modeling. Psychologica Methods, 1, 130-149. http://dx.doi.org/10.1037/1082-989X.1.2.130

Marsh, H. W., Balla, J. R., \& McDonald, R. P. (1988). Goodness of fit indexes in confirmatory factor analysis: The effects of sample size. Psychological Bulletin, 103, 391-410. http://dx.doi.org/10.1037/0033-2909.103.3.391

Marsh, H. W., \& Peart, N. (1988). Competitive and cooperative physical fitness training programs for girls: Effects on physical fitness and on multidimensional self-concepts. Journal of Sport and Exercise Psychology, 10, 390-407.

McCullick, B. A., Baker, T., Tomporowski, P. D., Templin, T. J., Lux, K., \& Isaac, T. (2012). An Analysis of State Physical Education Policies. Journal Of Teaching In Physical Education, 31(2), 200-210.

McFarlin, D.B., \& Rice, R.W. (1991). Determinants of satisfaction with specific job facets: A test of Locke's model. Journal of Business und Psychology, 6, 25-38. http://dx.doi.org/10.1007/BF01013683

Mitchell, S. A. (1996). Relationships between perceived learning environment and intrinsic 
motivation in middle school physical education. Journal of Teaching in Physical Education, 15, 369-383.

Ntoumanis, N. (2005). A prospective study of participation in optional school physical education using a self-determination theory framework. Journal of Educational Psychology, 97, 444-453. http://dx.doi.org/10.1037/0022-0663.97.3.444

Osborn, R. N., \& Hunt, J. G. (1975). An adaptive-reactive theory of leadership: The role of macro variables in leadership research. In J. G. Hunt \& L. L. Larson (Eds.), Leadership frontiers (pp. 27-44). Kent, OH: Kent State University.

Paradis, K. F., \& Loughead, T. M. (2012). Examining the mediating role of cohesion between athlete leadership and athlete satisfaction in youth sport. International Journal of Sport Psychology, 43(2), 117-136.

Pate, R. R., O'Neill, J. R., \& Mclver, K. L. (2011). Physical Activity and Health: Does Physical Education Matter?. Quest (00336297), 63(1), 19-35. http://dx.doi.org/10.1080/00336297.2011.10483660

Pescosolido, A. T. 2001. Informal leaders and the development of group efficacy. Small Group Research, 32, 74-93. http://dx.doi.org/10.1177/104649640103200104

Perry.C, Stone.E.J., Parcel.G.S., Ellison.R.C, Nader.P.R., Webber.L.S. \& Luepker.R.V. (1990). School-based cardiovascular health promotion: The Child and Adolescent Trial for Cardiovascular Health (CATCH). Journal of School Health, 60, 406-413. http://dx.doi.org/10.1111/j.1746-1561.1990.tb05960.x

Portman, P.A. (1995). Who is having fun in physical education classes? Experiences of six-grade students in elementary and middle schools. Journal of Teaching in Physical Education. 14, 445-453.

Price, M. S., \& Weiss, M. R. (2000). Relationships among coach burnout, coach behaviors, and athletes' psychological responses. The Sport Psychologist, 14(4), 391-409.

Quintana, S. M., \& Maxwell, S. E. (1999). Implications of recent developments in structural equation modeling for counseling psychology. The Counseling Psychologist, 27, 485- 527. http://dx.doi.org/10.1177/0011000099274002

Riemer, H. A., \& Chelladurai, P. (1995). Leadership and satisfaction in athletics. Journal of Sport and Exercise Psychology, 17, 276-293.

Riemer, H. A., \& Toon, K. (2001). Leadership and satisfaction in tennis: Examination of congruence, gender, and ability. Research Quarterly for Exercise and Sport, 72(3), 243-256. http://dx.doi.org/10.1080/02701367.2001.10608957

Ryan, R. M., Connell, J. P., \& Deci, E. L. (1985). A motivational analysis of self determination and self-regulation in education. In C. Ames, \& R. E. Ames (Eds.), Research on motivation in education: The classroom milieu (pp. 13-51). New York: Academic Press.

Sallis, J.F. (1987). A commentary on children and fitness: A public health perspective. 
Research Quarterly For Exercise and Sport, 58, 326-330. http://dx.doi.org/10.1080/02701367.1987.10608108

Sallis, J. E, \& McKenzie, T. L. (1991). Physical education's role in public health. Research $\begin{array}{lllll}\text { Quaretrly for Exercise } & \text { 124-157. }\end{array}$ http://dx.doi.org/10.1080/02701367.1991.10608701

Serpa, S., Lacoste, P., Pataco, V., \& Santos, F. (1988). Methodology of translation and adaptation of a specific sport test: A Leadership Scale for Sports. Paper presented at the $2^{\text {nd }}$ National Symposium on Psychology Research, Lisbon, Portugal.

Serpa, S., Pataco, V., \& Santos, F. (1991). Leadership patterns in handball international competition. International Journal of Sport Psychology, 22, 78-89.

Sharp, B. (1992). Acquiring skill in sport. Eastbourne, UK: Sport Dynamics.

Siedentop. D., \& O'Sullivan, M. (1992). Preface. Quest. 44, 285-286. http://dx.doi.org/10.1080/00336297.1992.10484055

Simons-Morton, B. G. (1994). Implementing health-related physical education. In R. R. Pate \& R. C. Hohn (Eds.), Health and fitness through physical education (pp. 137-146). Champaign, IL: Human Kinetics.

Slavin, R. E. (1990). Cooperative learning: theory, research, and practice. Boston, MA: Allyn \& Bacon.

Smith, R. E., \& Smoll, F. L. (1996). The coach as a focus of research and intervention in youth sports. In F. L. Smoll \& R. E. Smith (Eds.), Children and youth in sport. A biopsychosocial perspective (pp. 125-141). Dubuque, IA: Brown \& Benchmark.

Standage, M., Duda, J. L., \& Ntoumanis, N. (2005). A test of self - determination theory in school physical education. British Journal of Educational Psychology, 75(3), 411-433. http://dx.doi.org/10.1348/000709904X22359

Standage, M., Gillison, F. B., Ntoumanis, N., \& Treasure, D. C. (2012). Predicting Students'Physical Activity and Health-Related Well-Being: A Prospective Cross-Domain Investigation of Motivation Across School Physical Education and Exercise Settings. Journal Of Sport \& Exercise Psychology, 34(1), 37-60.

Steiger, J. H. (1989). Causal modeling: A supplementary module for SYSTAT and SYSGRAPH. Evanston, IL: SYSTAT.

Steiger, \& J.H., Lind, J. (1980). Statistically based tests for the number of common factors. Paper presented at the annual meeting of the Psychometric Society, Iowa City, IA.

Thomas, M. P. (1987). Zentralität als Selbstkonzeptaspekt: Eine Untersuchung zur Zentralitätvon subjektiven Fähigkeitskonzepten und objektiv gemessenen Fähigkeiten. Unveröffentlichte Dissertation, Freie Universität Berlin.

Trail, G. T. (2004). Leadership, cohesion, and outcomes in scholastic sports. International 
Journal of Sport Management, 5(2), 111-132.

Van Wersch, A., Trew, K., \& Turner, I. (1992). Post-primary school pupils' interest in physical education: Age and gender differences. British Journal of Educational Psychology, 62, 56-72. http://dx.doi.org/10.1111/j.2044-8279.1992.tb00999.x

Weiss, M. R. (1987). Self-esteem and achievement in children's sport and physical activity. In D. R. Gould, \& M. R. Weiss (Eds.), (pp. 87-119). Advances in pediatric sport sciences, 2. Champaign, IL: Human Kinetics.

Weiss, M. R. \& Friedrichs, W. D. (1986). The influence of leader behavior, coach attributes, and institutional variables on performance and satisfaction of collegiate basketball teams. Journal of Sport Psychology, 8, 332-346.

Wigfield, A., Eccles, J. S., Yoon, K. S., Harold, R. D., Arbreton, A. J. A., Freedman-Doan, C.

\& Blumenfeld, P. (1997). Change in children's competence beliefs and subjective task values across the elementary school years: A 3-year study. Journal of Educational Psychology, 89, 451-469. http://dx.doi.org/10.1037/0022-0663.89.3.451

Würth, S., Saborowski, C. \& Alfermann, D. (1999). Trainingsklima und Führungsverhalten aus der Sicht jugendlicher Athleten und deren Trainer. Psychologie und Sport, 6, 146-157.

Yukl, G. (1971). Toward a behavioral theory of leadership. Organizational Behavior and Human Performance, 6, 414-440. http://dx.doi.org/10.1016/0030-5073(71)90026-2

Zimmerman, B. J. (1990). Self-regulated learning and academic achievement: an overview. Educationa Psychologist, 25, 3-17. http://dx.doi.org/10.1207/s15326985ep2501_2 


\section{Appendix}

\section{LSS Items (translation of the German version)}

\begin{tabular}{|c|c|c|c|c|c|}
\hline For me it is important that my PE teacher... & never & seldom & occasionally & often & always \\
\hline $\begin{array}{l}\text {.. explains how each student's contribution fits into the } \\
\text { whole picture }\end{array}$ & $\square$ & $\square$ & $\square$ & $\square$ & $\square$ \\
\hline ... points out each student's strengths \& weaknesses & $\square$ & $\square$ & $\square$ & $\square$ & $\square$ \\
\hline ... expresses appreciation when a student performs well & $\square$ & $\square$ & $\square$ & $\square$ & $\square$ \\
\hline ... figures ahead on what should be done & $\square$ & $\square$ & $\square$ & $\square$ & $\square$ \\
\hline ...looks out for the personal welfare of the students & $\square$ & $\square$ & $\square$ & $\square$ & $\square$ \\
\hline $\begin{array}{l}\text {... explains to every student what he should and should not } \\
\text { do }\end{array}$ & $\square$ & $\square$ & $\square$ & $\square$ & $\square$ \\
\hline $\begin{array}{l}\text {... compliments a student on his performance in front of } \\
\text { others }\end{array}$ & $\square$ & $\square$ & $\square$ & $\square$ & $\square$ \\
\hline $\begin{array}{l}\text {.. gets group approval on important matters before going } \\
\text { ahead }\end{array}$ & $\square$ & $\square$ & $\square$ & $\square$ & $\square$ \\
\hline$\ldots$ lets the group set it's own goals & $\square$ & $\square$ & $\square$ & $\square$ & $\square$ \\
\hline ... tells a student when he does a particularly good job & $\square$ & $\square$ & $\square$ & $\square$ & $\square$ \\
\hline $\begin{array}{l}\text {.. encourages students to make suggestions for ways of } \\
\text { conducting practices }\end{array}$ & $\square$ & $\square$ & $\square$ & $\square$ & $\square$ \\
\hline ... lets his students share in decision making & $\square$ & $\square$ & $\square$ & $\square$ & $\square$ \\
\hline $\begin{array}{l}\ldots \text { gives specific instructions to each student as to what } \\
\text { he should do in every situation }\end{array}$ & $\square$ & $\square$ & $\square$ & $\square$ & $\square$ \\
\hline ... sees that a student is rewarded for a good performance & $\square$ & $\square$ & $\square$ & $\square$ & $\square$ \\
\hline $\begin{array}{l}\ldots \text { asks for the opinion of the students on strategies for } \\
\text { specific exercises }\end{array}$ & $\square$ & $\square$ & $\square$ & $\square$ & $\square$ \\
\hline $\begin{array}{l}\text {... instructs every student individually in the skills of the } \\
\text { sport }\end{array}$ & $\square$ & $\square$ & $\square$ & $\square$ & $\square$ \\
\hline ... sees to it that every student is working to his capacity & $\square$ & $\square$ & $\square$ & $\square$ & $\square$ \\
\hline ... helps the students with their personal problems & $\square$ & $\square$ & $\square$ & $\square$ & $\square$ \\
\hline ... encourages the students to confide in him & $\square$ & $\square$ & $\square$ & $\square$ & $\square$ \\
\hline ... helps members of the class settle their conflicts & $\square$ & $\square$ & $\square$ & $\square$ & $\square$ \\
\hline $\begin{array}{l}\ldots \text { asks for the opinion of students on important education } \\
\text { matters }\end{array}$ & $\square$ & $\square$ & $\square$ & $\square$ & $\square$ \\
\hline
\end{tabular}




\section{Copyright Disclaimer}

Copyright reserved by the author(s).

This article is an open-access article distributed under the terms and conditions of the Creative Commons Attribution license (http://creativecommons.org/licenses/by/3.0/). 